\title{
A Classification Study on the Development Stages of Construction Technologies in Turkey
}

\author{
Halil Ibrahim Polat \\ Ministry of Environment and Urban Planning \\ Istanbul, Turkey \\ halilibrahimpolat34@gmail.com
}

\begin{abstract}
Developmental stages of construction technologies in Turkey followed various methods and showed differences in practice up to 20th century when the first examples of earlyperiod reinforced concrete structures was created. Following the late 18th century, when traditional construction techniques were applied to new masses and building types, the use of modern bricks in vertical carrier elements together with the means of the 19th century was followed by an increase in masonry construction types of building structures. The paper emphasizes in the effects of traditional construction techniques applied with brick, steel, concrete materials on construction technology in Turkey. Traditional construction techniques are classified and detailed evaluations are made on the design principles of the buildings with historical characteristics.
\end{abstract}

Keywords-construction technology; brick arc floor; ferroconcrete; early reinforced concrete structures

\section{INTRODUCTION}

The 20th century modern architectural theme is a complex area and can be diverted differently depending on where the researcher is standing [1]. It had become inevitable for the Ottoman State to be exposed to influences at the point of architectural and engineering applications and to incorporate domestic and imported ideas into the framework of westernization starting from the Tanzimat (the political reforms made in the Ottoman State) years. This relationship has affected construction elements, constructive behavior, facade applications, material usage and carrier system selection. In this context, with the help of both architectural and engineering terminology, an eye was kept on the construction techniques used in the past between the westernization period architecture that started to take effect in the Ottoman Empire since the second half of the 19th century and the early reinforced concrete technology that lasted until the 1940s. In the late 19th century, mainly due to large fires, the building materials were transferred from the wooden material to the masonry system consisting of stone and bricks.

In this paper, developmental stages of construction technology are discussed in the context of purely carrier systems. It is attempted to establish a classification proposal from the written and visual documents about certain special buildings by determining which types of vertical and horizontal elements are used for tensile stress and bending loads. The basic nuance in this classification is based on the composite construction technology (masonry+brick arch floor, framework+brick arch floor, ferroconcrete, reinforced concrete, etc). Studied structures have been confined to Istanbul, the locomotive of the westernization phenomenon in Turkey. The mentioned buildings consist of monumental structures as well as structures registered in the state inventory and private properties. In [2], the author set out from the early 18 th century traditional construction techniques, based on the process leading up to the westernization period when making his classification. He gave examples from the wooden skeletal systems. He narrated the development of masonry (stone and brick) from the middle of the 18th century and talked about the horizontally brick arch floor technique which gave its first yields in the late 19th century. At the beginning of the 20th century, the steel skeleton system was used in vertical and horizontal directions. In the same period, the steel and concrete together with ferroconcrete construction technology had been integrated into the new buildings and finally the reinforced concrete structure system was used in all structural elements.

The classification method used in [2] is the cause of the path of the article. Starting from the late 19th century, stacked masonry is chosen as the starting point of the horizontal voltaic laying system, where composite construction technology was dominant. The process continued until the first examples of the horizontal and vertical reinforced concrete system. According to this study, reaching up to the first decade of the young Republic of Turkey, the divisions of the construction technology used are:

- Masonry + Brick arch floor

- Masonry + Steel frame + Brick arch floor

- Steel frame + Brick arch floor

- Ferroconcrete

- Steel frame + Reinforced concrete

- Masonry + Reinforced concrete

- Reinforced concrete 
Given this classification, one must consider the intricate approaches in the selection of the bearing systems in some buildings, the direction of the progress of the technology in restoration, where especially the flooring systems and masonry walls transformed into reinforced concrete columns. Steel column reinforcements were also made in the structures where ferroconcrete technology was used. But however, the classification is based on the original carrier system. It is difficult to talk about a unification in the architectural context between the periods of the destruction of the Ottoman State and the establishment of the Republic of Turkey. While studying the structure, it can be seen that the architects and engineers of this period used mixed systems. For example there are buildings which are of vertical masonry, horizontally brick arch floor, while steel beams and concrete, which is ferroconcrete system, can be found in the load bearing system of the building. Hence, the method of classification of each structure can be based on one's conviction. The time scope of this classification extends from the last quarter of the 19th century to the first quarter of the 20th century (approximately 50 years) and is limited to Istanbul, with more than 200 structures having been researched.

\section{CLASSIFICATION OF CONSTRUCTION TECHNOLOGIES}

Beyoglu-Karakoy, Galata, Tepebasi, Historical Peninsula in Eminonu, Sirkeci, Gulhane, Beyazit, Sisli, Tesvikiye, Bomonti, Besiktas, Akaretler, Kadikoy, Haydarpasa and Moda stand out as the new architectural point of view and a reflection of production technologies in Istanbul, which tends to be westernized. The data of structures ranging from single-floor to 10 floor buildings, which were built in this period is further investigated. The usual number of floors studied varied between 3 and 4 . It has been concluded that the original architectural and structural system of approximately $25 \%$ of the structures is changed by restoration. It is determined that the private property concrete structures, which were built especially in the early years of Turkish Republic have been demolished. This practice has sprung up the old structures which are built in the brick arch floor and ferroconcrete system. The current function of the majority of the buildings is commercial, educational, residential and hotels. In Karakoy French architect Alexandre Vallaury, in Yildiz Italian Raimondo D'Aronco, in the historical peninsula architect Kemalettin Bey who are the pioneers of the First National Architecture Movement and Vedat Tek who has worked on new construction technologies, are authorized by the state in the construction of many buildings. There is a transitive between the years when these construction technologies were used and of the years left to be used. At the same time, the criterion applied for ranking is determined by the behavior and variability of the production technologies.

\section{A. Masonry + Brick Arch Floor}

In the last quarter of the 19th century brick and steel, which are mass production based materials, started to be used as composite building materials, leaving behind wood which has a low fire resistance and stone which has a high labor cost. So, the brick arch floor is only used as horizontal load bearings.
Brick arch floor is a type of slab where approximately 0.50 $0.60 \mathrm{~m}$ small brick vaults are placed between parallel steel beams [3]. The brick arch floors running in the horizontal direction provide load transfer to the vertical walls which are vertical load bearings. The transfer is by means of steel beams. It is thought that the first building that was built in Istanbul with this construction technique was the Macka Silahhane (1873-1875) [4]. The brick arch floor of the building which functions as Istanbul Technical University Macka Campus was transformed into reinforced concrete floors in 1955. Besides, the German Consulate, Cicek Pasaji, Akaretler, Balikli Greek Hospital, Pera Palas Otel and Italian Salesiani School are among the most known examples of this building technology. Bomonti Brewery Administration Building and Boiling Oven Building (1920-1924) are among the latest and most important structures that were built in masonry + brick arch floor system [5].

\section{B. Masonry + Steel Frame + Brick Arch Floor}

Buildings built in this technology are located in Galata along Bankalar Caddesi and Gumruk road. In particular, it has been found that steel profiles are used in addition to the vertical load bearing wall at the elevator sections and at the central points of the structures. The most well-known example is Omer Abed Han designed by Alexandre Vallaury in Karakoy [6]. The 5-floor building, which was built in 1902, now functions as a business center (Figure 1) [7].

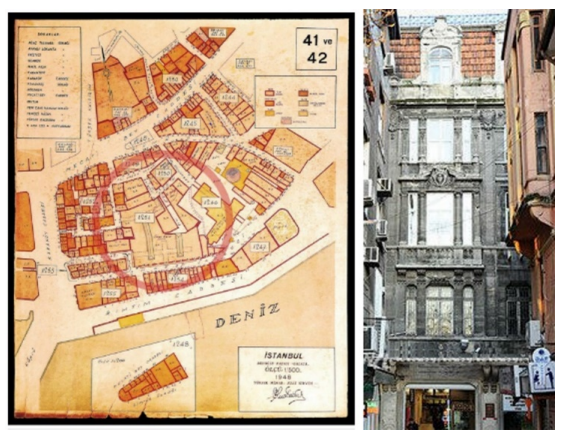

Fig. 1. Omer Abed Han (on Pervitich maps and at present)

\section{Steel Frame + Brick Arch Floor}

In Ottoman architecture, iron was not used as a loadbearing element alone, but as an auxiliary element that only supports the principal elements carrying loads [8]. On the other hand, in the vertical direction, only the steel beam was used instead of the masonry wall. The first known example is the 6floor British Marines Hospital (1901-1904) located in Galata [9]. The most popular example of this building technology can be said to be Haydarpasa Train Station which is one of the symbols of Istanbul. The building was built in German 'New Renaissance' style between 1906 and 1908 and it was built on gigantic steel beams, brick arch flooring being used as a horizontal load transfer element (Figure 2). Bostanci Pier and Tunel (Metro) Han, built in the first quarter of the 20th century, are also examples of this construction technique [10] 


\section{Ferroconcrete}

At the beginning of the 20th century, masonry (stone and brick) materials were inadequate for the design of large and monumental structures. Also, a new material was needed instead of the steel due to its high cost at the time in question. Concrete was the material produced as a result of this need. However, there are some drawbacks of concrete being a standalone building element. Because concrete is a structural element which is resistant to pressure (ductile) but cannot show resistance against tensile stresses that can cause brittle fracture. For this reason, the discovered ferroconcrete technology takes as principle the joint placing with steel beams (bending strength) and concrete (compressive strength). And it is considered as an important construction technology accelerating the transition process to reinforced concrete construction technique. In this system, the horizontal loads are transferred to the vertical elements with the aid of ferroconcrete beams by closing the spaces above and by using an improved form of the brick arch floor technique. Eminonu Post and Telegraph Building (1905, Architect Vedat Tek) and Galata Customs Buildings Warehouses (1907-1910) are examples of early ferroconcrete applications [11]. Vedat Tek's Defter-i Hakani Building (1908), Nemlizade Tobacco Warehouse (1912) and Liman Han (1912) on which demolition decision is taken due to laying $3^{\circ}$ towards the sea in Sirkeci are the extant products of ferroconcrete technology. In addition, Assicurazioni Generali Han (1909-1923) and Wiener BankVerein (Karakoy Ziraat Bank, 1911-1912) by the architect Giulio Mongeri are built with ferroconcrete system. Central Rihtim Han (1912-1914), which is one of the symbols of Galata, was destroyed under the name of repair and conversion to hotel, due to Galataport project during the days of this study (Figure 3).

\section{E. Steel Frame + Reinforced Concrete}

In the ferroconcrete construction technique, concrete and steel work as composite building elements. In the 2nd Machinery and Boiler Houses between Silahtaraga Power Plant Buildings in Alibeykoy, a construction system where vertically oriented concrete beams are placed separately with heavy steel beams is used. Second Engine House (1921) was built in steel cage columns sitting on a reinforced concrete foundation plate of $0.70 \mathrm{~m}$. The foundation plaque is strengthened by reinforced concrete foundation pile of $7.3 \mathrm{~m}$ length and $0.25 / 0.25 \mathrm{~m}$ crosssection [12]. Second Boiler House (1929) is constructed of a reinforced concrete plate on which the metal structure is placed and columns under it (Figure 4).

\section{F. Masonry + Reinforced Concrete}

This construction technology is not a composite technique like steel frame + reinforced concrete. The vertical masonry is formed by placing reinforced concrete plates on the masonry wall. Also, it is consisted of reinforced concrete columns which are articulated in the wall in the wall's direction. In the years when the reinforced concrete systems which are designed in the mixed model have become widespread and they are found in Kadikoy, Fatih and Sisli. The majority of the samples which are built between 1930 and 1938 such as Prof. Dr. Ahmet Agaoglu House [13] (Figure 5), Eczaci Nazim Malkoc House
[14], A House at Feneryolu [15], the Behcet Unmeric House [16], did not reach the todays time.

\section{G. Reinforced concrete}

The discovery of concrete is based on the need for a combination of concrete with high compressive strength and steel that meets tensile stresses. It was the American T. Hyatt that first brought the idea of using concrete and steel together in the event of bending. In 1901 Auquste and Gustave Perret performed the first application of the reinforced concrete skeletal system. Shortly after the discovery of the reinforced concrete building element, the first yields were revealed in the Saint Antoine Church (1906-1911) and Apartments (19061912) on Istiklal Avenue (Figure 6). These constructions designed by architects Giulio Mongeri and Eduardo de Nari were recorded as the first concrete example of the Ottoman period [17]. The columns in the building, the beams that connect them to each other, arches and vaults which covers roof are all built as reinforced concrete [18]. Until the 1930s, the monumental buildings in reinforced concrete technology structures which were generally handled by the state were in hospital, pier, factory and apartment buildings functions. Seyr-i Sefain Building (1912), Moda Pier (1915) and Nemlizade Tobacco Warehouse (1925) by Vedat Tek [19], Harikzedegan Apartments (1919-1922) by Kemalettin Bey, Sureyya Opera House (1924-1927) by A. and G. Perret are among the main examples (Figure 7) [20]. Many apartment buildings belonging to private property, which represent Republican era Istanbul architecture, were constructed with reinforced concrete construction technology between 1930 and 1940. Unique apartment buildings by the famous architects such as Abidin Mortas, Zeki Sayar, Sedad Hakki Eldem, T. Cubukciyan ve Ekrem Hakki Ayverdi were located in Gumussuyu, Nisantasi, Bahariye where the people have high educational level [21]. Most of these constructions are designed with a beam-column frame structure. However, unfortunately a considerable number of these buildings have been destroyed before they reached the present day. Dervis Bey Apartment (6 floors, in Cihangir, 1930-1932), Bosfor Apartment (10 floors, in Gumussuyu, 1930-1932), Sevket Bey Apartment (5 floors, in Fatih, 19301933), Rontgen Apartment (5 floors, in Bahariye, 1930 -1933), Seza Apartment (5th floor, in Muhurdar, 1930-1933), Halit Ziya Bey Apartment (5th floor, in Cemberlitas, 1930-1934), Dr. Ziya Zeren House (4th floor, in Bahariye, 1930-1935) which are in the city's memory as qualified constructions was demolished and replaced with new buildings. Tahir Khan, which was built in 1934, is one of the Early Republican concrete structures built in Karakoy, Gumruk Caddesi. The architect Vedat Tek structure, which is composed of 6 floors, is now abandoned (Figure 8).

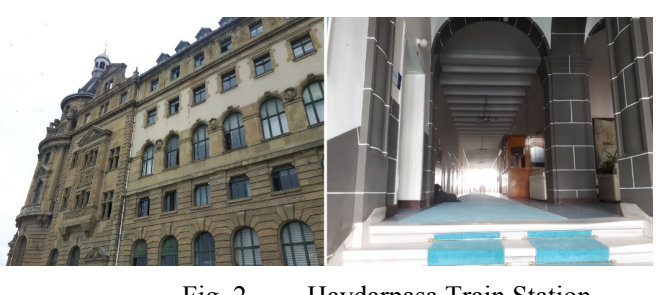

Fig. 2. Haydarpasa Train Station 


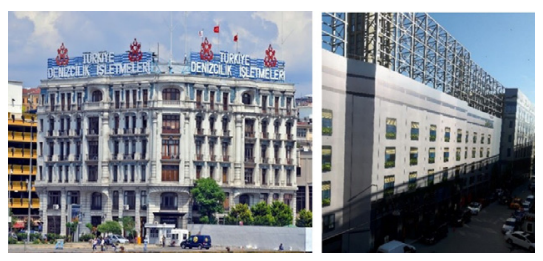

Fig. 3. The Rihtim Han Center

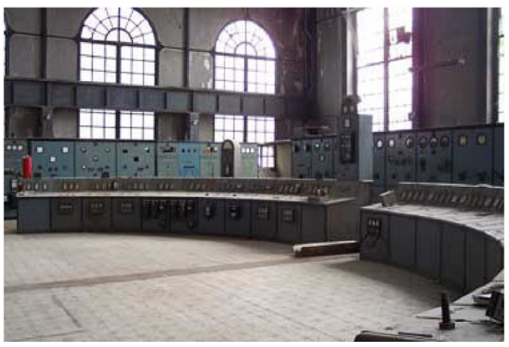

Fig. 4. Silahtaraga Electric Power Plant, 2nd Engine House
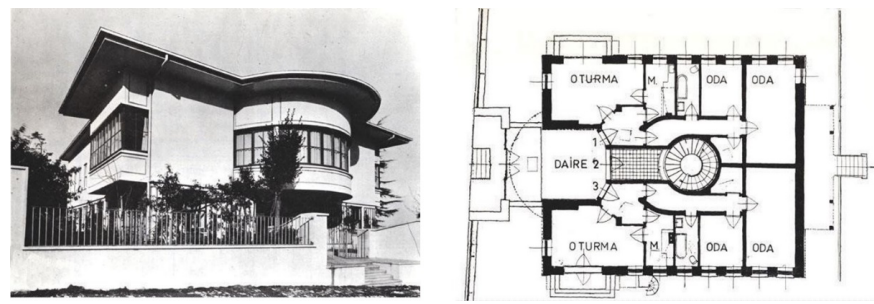

Fig. 5. Prof. Dr. Ahmet Agaoglu House

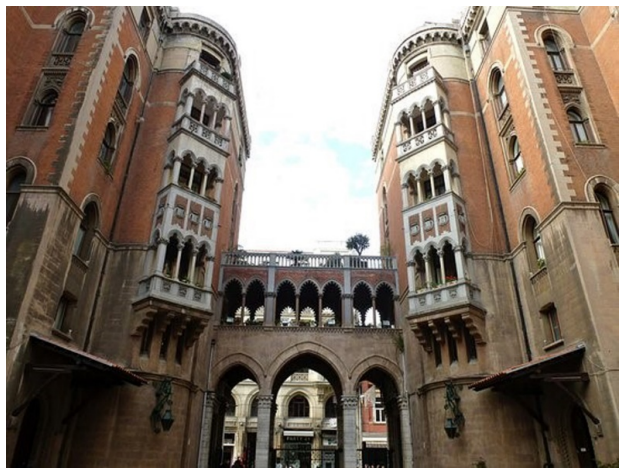

Fig. 6. Sant'Antoine Church and its apartments

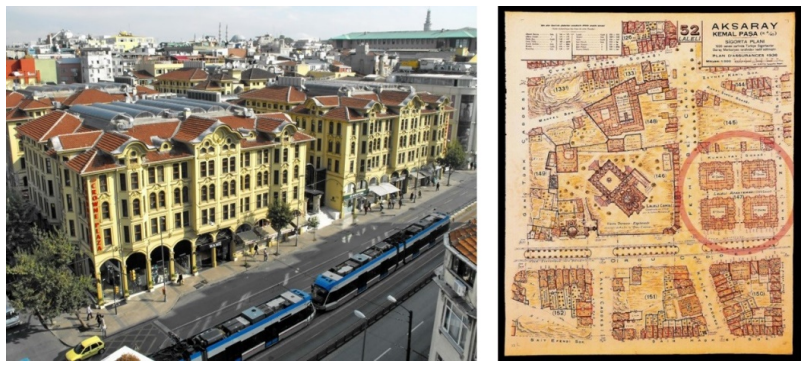

Fig. 7. Harikzedegan apartments (at present and on Pervitich maps)
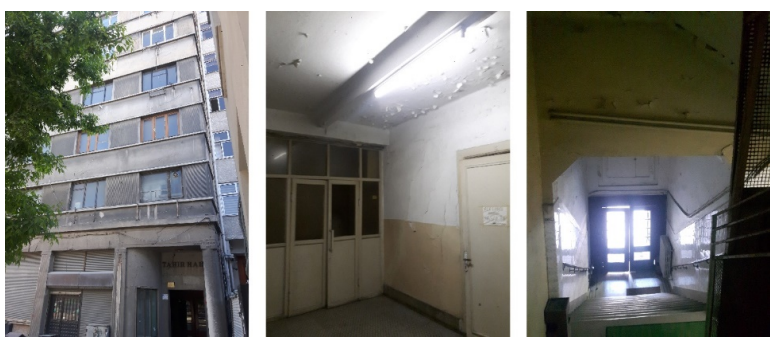

Fig. 8. Tahir Han

There are still standing buildings which are symbolizing the early years of the Young Republic of Turkey, especially in the Beyoglu and Sisli regions. Istiklal, Ceylan, Pertev and Cumhuriyet Apartments in Gumussuyu, Tuten Apartment in Ayaspasa, Melek Apartment in Nisantasi and Gevrek Apartment in Talimhane are trying to move to next generations even if they are under the threat of construction by contractors who want to make investments there.

\section{CONCLUSION AND EVALUATION}

A variety of construction techniques is visible in buildings in Istanbul, depicting the technological and cultural changes throughout the ages. A classification of the different techniques could prove valuable for contemporary architectural orientations and for the preservation of originality in possible restoration works. In this paper, the classification carried out was based on load bearing system. The vast majority of the buildings considered are state monumental buildings. The classification scheme followed can not be absolutely accurate as it is not always easy to define the load-bearing system of every structure. Further, restoration works have also an impact on the load-bearing system used. However, it offers a useful road-map for classifying different structures and understanding the architectural history of Istanbul.

\section{REFERENCES}

[1] S. O. Gur, S. Durmus, "Tarihyazimina Bir Kayit Dusmek", Yapi No 425, pp. 74-80, 2017

[2] U. Yergun, Batililasma Donemi Mimarisinde, Yapim Teknolojisindeki Degisim ve Gelisim, Yildiz Technical University Institute of Science, PhD Thesis, Istanbul, 2002

[3] M. Sozen, U. Tanyeli, "Sanat Kavram ve Terimleri Sozlugu”, Remzi Press, Istanbul, pp. 317-318, 2014

[4] http://www.tas-Istanbul.com/portfolio-view/macka-silahhanesi/

[5] G. Tanyeli, D. Ikiz, "Istanbul'da Bir Endustriyel Miras Ornegi: Bomonti Bira Fabrikasi”, Turkiye Bilimer Akademisi, 7, 2009

[6] M. S. Akpolat, Fransiz Kokenli Levanten Mimar Alexandre Vallaury, Hacettepe University Institute of Social Science, PhD Thesis, Ankara, 1991

[7] J. Pervititich, Sigorta Haritalarinda Istanbul, Tarih Vakfi Yurt Press, Axa Oyak, Istanbul, 2003

[8] U. Tanyeli, Osmanli Mimarliginda Demirin Strukturel Kullanimi (15-18 y.y.), Istanbul Technical University Institute of Science, PhD Thesis, Istanbul, 1996

[9] S. Genim, Panorama Istanbul 1955, Masa Press, Istanbul, 2017

[10] C. Kiziltug, Tunel (1875-1990), Istanbul, 1990

[11] T. Uzun, Gec Osmanli- Erken Cumhuriyet Donemi Mimarlik Pratiginde Bilgi ve Yapim Teknolojileri Degisimi Erken Betonarme Istanbul Ornekleri: 1906-1930, Yildiz Technical University Institute of Science, Istanbul, 2008 
[12] S. Y. Brangar, Silahtaraga Elektrik Santrali'nin Korunmasi ve Yeniden Kullanimina Yonelik Oneriler, Yildiz Technical University Institute of Science, MSc Thesis, Istanbul, 2004

[13] Anonim, Macka'da Profesor Ahmet. Agaoglu Evi, Arkitekt Journal, 1011, Istanbul, 1938

[14] A. Mortas, "Eczaci Nazim Malkoc Evi", Arkitekt Journal, 4, Istanbul, 1937

[15] A. Denktas, "Feneryolu'nda Bir Ev", Arkitekt Journal, 9, Istanbul, 1937

[16] N. Akatay, "Behcet Unmeric Evi “, Arkitekt Journal, 1-2, Istanbul, 1939

[17] C. Can, P. Girardelli, "Beyoglu'nda Bir Latin Aniti”, Yasayan CizgilerSant'Antoine Kilisesi Mimari Cizimler Sergisi, Yapi Kredi Culrural Center, Istanbul, 1996

[18] C. Can, Istanbul'da 19. Yuzyil Batili ve Levanten Mimarlarin Yapilari ve Koruma Sorunlari, Yildiz Technical University Institute of Science, PhD Thesis, Istanbul, 1993

[19] H. Pilehvarian, "Moda Iskelesi", Mimarlik Dekorasyon, sayi: 97, Istanbul, 1997

[20] Y. Yavuz, Birinci Ulusal Mimarlik Donemi ve Mimar A. Kemalettin Bey, Istanbul Technical University Institute of Science, $\mathrm{PhD}$ Thesis, Istanbul, 1981

[21] D. Ozakbas, Cumhuriyet Donemi (1923-1940) Istanbul Mimarisi, Mimar Sinan Guzel Sanatlar University Institute of Social Sciences, MSc Thesis, Istanbul, 2007 